\title{
Growth performance and carcass quality of broilers as affected by light flashes program in relation to dietary vitamin $\mathrm{d} 3$ levels (Abstract)
}

\author{
M. F. A. Farghly ${ }^{1}$ and Enas A. M.Ahmad ${ }^{2}$ \\ ${ }^{1}$ Dept. of poultry Production, Fac. Of Agric., Univ. of Assiut, Egypt \\ ${ }^{2}$ Dept. of Animal and Poultry Production, Fac.of Agri., and Natural Resources, Aswan Univ., Egypt \\ Corresponding Author:farghly20002000@yahoo.com\& farghly20002000@aun.edu.eg
}

\begin{abstract}
This study was undertaken to determine the effect of dietary vitamin D supplementation in relation to light flash program on the growth performance, carcass traits, meat quality, some blood parameters and economic efficiency of broiler chickens. Therefore, 270 birds were randomly distributed into three main groups and housed in floor pens and reared under continues light for $24 \mathrm{hrs}$ per day; $16 \mathrm{hrs}$ continues light $+8 \mathrm{~h}$ flash light/day and $8 \mathrm{hrs}$ continues light +16 hrs flash light/day, respectively. Each main group were divided into 3 equal groups (60 birds each) and received 0,100 and $200 \mathrm{ppm}$ vitamin D from 4 wks till six weeks of age. Main results could be summarized as follows: light flash program significantly affected body weight, daily weight gain, feed conversion, dressed carcass, some blood traits as T3 hormone, leg problems, lymphoid organs and body temperature. However, it had insignificant effects on most meat quality traits. In addition, the body weight and body weight gain were significantly increased at all levels of dietary vitamin D. The liver, bursa and breast weights (expressed as percent of body weight) increased significantly with diet containing 100 or 200 ppm vitamin D. Meat quality traits, bone measurements and plumage conditions significantly affected by all levels of dietary vitamin D. Plasma protein, glucose, AST and ALT activities increased significantly in birds fed diets added $200 \mathrm{ppm}$ vitamin D levels. Economic efficiency of the broiler chickens was precisely improved at levels of $100 \mathrm{ppm}$ dietary vitamin D with second program of flash light ( $16 \mathrm{hrs}$ continues light $+8 \mathrm{~h}$ flash light/day) .
\end{abstract}

Key Words: light flash and vitamin D, performance, broiler chickens) 
